\title{
Distance Dependence of Photoinduced Long-Range Electron Transfer in Zinc/Ruthenium-Modified Myoglobins
}

\author{
Andrew W. Axup, Michael Albin, Stephen L. Mayo, Robert J. Crutchley, ${ }^{1}$ and \\ Harry B. Gray*
}

Contribution No. 7588 from the Arthur Amos Noyes Laboratory, California Institute of Technology, Pasadena, California 91125. Received May 8,1987

\begin{abstract}
An experimental investigation of the distance dependence of long-range electron transfer in zinc/ruthenium-modified myoglobins has been performed. The modified proteins were prepared by substitution of zinc mesoporphyrin IX diacid ( $\mathrm{ZnP})$ for the heme in each of four previously characterized pentaammineruthenium(III) $\left(a_{5} \mathrm{Ru} ; \mathrm{a}=\mathrm{NH}_{3}\right)$ derivatives of sperm whale myoglobin $(\mathrm{Mb})$ : $\mathrm{a}_{5} \mathrm{Ru}\left(\right.$ His-48) $\mathrm{Mb}, \mathrm{a}_{5} \mathrm{Ru}\left(\right.$ His-12) $\mathrm{Mb}, \mathrm{a}_{5} \mathrm{Ru}\left(\right.$ His-116) $\mathrm{Mb}, \mathrm{a}_{5} \mathrm{Ru}($ His-81) $\mathrm{Mb}$. Electron transfer from the $\mathrm{ZnP}$ triplet excited state $\left({ }^{3} \mathrm{ZnP}^{*}\right)$ to $\mathrm{Ru}^{3+},{ }^{3} \mathrm{ZnP}^{*}-\mathrm{Ru}^{3+} \rightarrow \mathrm{ZnP}^{+}-\mathrm{Ru}^{2+}\left(\Delta E^{\circ} \sim 0.8 \mathrm{~V}\right)$ was measured by time-resolved transient absorption spectroscopy: rate constants $\left(k_{\mathrm{f}}\right)$ are $7.0 \times 10^{4}(\mathrm{His}-48), 1.0 \times 10^{2}$ (His-12), $8.9 \times 10^{1}$ (His-116), and $8.5 \times 10^{1}$ (His-81) s ${ }^{-1}$ at $25^{\circ} \mathrm{C}$. Activation enthalpies calculated from the temperature dependences of the electron-transfer rates over the range $5-40^{\circ} \mathrm{C}$ are $1.7 \pm 1.6$ (His-48), $4.7 \pm 0.9$ (His-12), $5.4 \pm 0.4$ (His-116), and $5.6 \pm 2.5$ (His-81) kcal mol ${ }^{-1}$. Electron-transfer distances ( $d=$ closest $\mathrm{ZnP}$ edge to $\mathrm{a}_{5} \mathrm{Ru}(\mathrm{His})$ edge; angstroms) were calculated to fall in the following ranges: His-48, 11.8-16.6; His-12, 21.5-22.3; His-116, 19.8-20.4; His-81, 18.8-19.3. The rate-distance equation is $k_{\mathrm{f}}=7.8 \times 10^{8}$ $\exp [-0.91(d-3)] \mathrm{s}^{-1}$. The data indicate that the ${ }^{3} \mathrm{ZnP}-\mathrm{Ru}(\mathrm{His}-12)^{3+}$ electronic coupling may be enhanced by an intervening tryptophan (Trp-14).
\end{abstract}

Long-range electron transfers are important mechanistic steps in many biological oxidation-reduction reactions. ${ }^{2-16}$ Although

(1) Present address: Department of Chemistry, Carleton University, Ottawa, Canada K1S 5B6.

(2) Hatefi, Y. Annu. Rev. Biochem. 1985, 54, 1015-1069.

(3) Dixit, B. P. S. N.; Vanderkooi, J. M. Curr. Top. Bioenerg. 1984, 13, $159-202$

(4) Michel-Beyerle, M. E.; Ed. Antennas and Reaction Centers of Photosynthetic Bacteria; Springer-Verlag: Berlin, 1985.

(5) De Vault, D. Quantum Mechanical Tunnelling in Biological Systems, 2nd ed.; Cambridge University: Cambridge, 1984.

(6) Sykes, A. G. Chem. Soc. Rev. 1985, 14, 283-315.

(7) Brunschwig, B. S.; DeLaive, P. J.; English, A. M.; Goldberg, M.; Gray,

H. B.; Mayo, S. L.: Sutin, N. Inorg. Chem. 1985, 24, 3743-3749.

(8) (a) Gray, H. B. Chem. Soc. Rev. 1986, 15, 17-30. (b) Mayo, S. L.; Ellis, W. R., Jr.; Crutchley, R. J.; Gray, H. B. Science (Washington, D.C.) 1986, 233, 948-952.

(9) (a) Yocom, K. M.; Shelton, J. B.; Shelton, J. R.; Schroeder, W. A.; Worosila, G.; Isied, S. S.; Bordignon, E.; Gray, H. B. Proc. Natl. Acad. Sci. U.S.A. 1982, 79, 7052-7055. (b) Winkler, J. R. Nocera, D. G.: Yocom, K. M.; Bordignon, E.; Gray, H. B. J. Am. Chem. Soc. 1982, 104, 5798-5800. (c) Yocom, K. M.: Winkler, J. R.; Nocera, D. G.; Bordignon, E.; Gray, H. B. Chem. Scr. 1983, 21, 29-33. (d) Kostic, N. M.; Margalit, R.; Che, C.-M.; Gray, H. B. J. Am. Chem. Soc. 1983, 105, 7765-7767. (e) Margalit, R. Kostic, N. M.; Che, C.-M.; Blair, D. F.; Chiang, H.-J.; Pecht, I.; Shelton, J. B.; Shelton, J. R.; Schroeder, W. A.; Gray, H. B. Proc. Natl. Acad. Sci. U.S.A. 1984, 81, 6554-6558. (f) Nocera, D. G.; Winkler, J. R.; Yocom, K. M.; Bordignon, E.; Gray, H. B. J. Am. Chem. Soc. 1984, 106, 5145-5150. (g) Crutchley, R. J.; Ellis, W. R., Jr.; Gray, H. B. J. Am. Chem. Soc. 1985, I07, 5002-5004. (h) Lieber, C. M.; Karas, J. L.; Gray, H. B. J. Am. Chem. Soc. 1987, 109, 3778-3779.

(10) Crutchley, R. J.; Ellis, W. R., Jr.; Gray, H. B. Frontiers in Bioinorganic Chemistry; Xavier, A. V., Ed.; VCH: Weinheim, FRG, 1986; pp 679-693. Crutchley, R. J.; Ellis, W. R., Jr.; Shelton, J. B.; Shelton, J. R.; Schroeder, W. A.; Gray, H. B., to be submitted for publication.

(11) Axup, A. W. Ph.D. Thesis, California Institue of Technology, Pasadena, CA, 1987

(12) (a) Isied, S. S.; Worosila, G.; Atherton, S. J. J. Am. Chem. Soc. 1982 , 104, 7659-7661. (b) Isied, S. S.; Kuehn, C.; Worosila, G. J. Am. Chem. Soc. 1984, 106, 1722-1726. (c) Bechtold, R.; Gardineer, M. B.; Kazmi, A.; van Hemelryck, B.; Isied, S. S. J. Phys. Chem. 1986, 90, 3800-3804. (d) Bechtold, R.; Kuehn, C.; Lepre, C.; Isied, S. S. Nature (London) 1986, 322, 286-288. (13) (a) McGourty, J. L.; Blough, N. V.; Hoffman, B. M. J. Am. Chem Soc. 1983, 105, 4470-4472. (b) Ho, P. S.; Sutoris, C.; Liang, N.; Margoliash, E.; Hoffman, B. M. J. Am. Chem. Soc. 1985, 107, 1070-1071. (c) Peterson-Kennedy, S. E.; McGourty, J. L.; Kalweit, J. A.; Hoffman, B. M. J. Am. Chem. Soc. 1986, 108, 1739-1746.

(14) Liang, N.; Pielak, G. J.; Mauk, A. G.; Smith, M.; Hoffman, B. M. Proc. Natl. Acad. Sci. U.S.A. 1987, 84, 1249-1252.

(15) (a) Simolo, K. P.; McLendon, G. L.; Mauk, M. R.; Mauk, A. G. J. Am. Chem. Soc. 1984, 106, 5012-5013. (b) McLendon, G. L.; Winkler, J. R.; Nocera, D. N.; Mauk, M. R.; Mauk, A. G.; Gray, H. B. J. Am. Chem. Soc. 1985, 107, 739-740. (c) McLendon, G.; Miller, S. R. J. Am. Chem. Soc. 1985, 107, 7811-7816. (d) Cheung, E.; Taylor, K.; Kornblatt, J. A.; English, A. M.; McLendon, G. L.; Miller, J. R. Proc. Natl Acad. Sci. U.S.A. 1986, 83, 1330-1333. (e) Conklin, K. T.; McLendon, G. L. Inorg. Chem. 1986, 25, $4804-4806$. it is generally assumed that the rates of these transfers are determined to a large extent by the donor-acceptor separation and the nature of the intervening medium, ${ }^{17-21}$ very few experiments have addressed these points in a systematic manner, ${ }^{7,8,11}$

One approach to the study of long-range electron transfer is to attach a redox-active complex to a specific surface site of a structurally characterized heme or blue copper protein, thereby producing a two-site molecule with a fixed donor-acceptor distance. The redox-active complex that has been employed successfully in several previous experiments is $\mathrm{a}_{5} \mathrm{Ru}^{2+/ 3+}\left(\mathrm{a}=\mathrm{NH}_{3}\right)$, which covalently bonds to surface histidines. ${ }^{8-12}$ This complex can be attached by the reaction of $a_{5} \mathrm{Ru}\left(\mathrm{OH}_{2}\right)^{2+}$ with native protein under mild conditions, and the ruthenated protein can be purified by ion-exchange chromatography.

In order to probe distance effects on long-range electron transfer, we have replaced the heme in four ruthenated myoglobins $\left(a_{5} \mathrm{Ru}(\mathrm{His}-48) \mathrm{Mb} ; \mathrm{a}_{5} \mathrm{Ru}(\mathrm{His}-12) \mathrm{Mb} ; \mathrm{a}_{5} \mathrm{Ru}(\mathrm{His}-116) \mathrm{Mb} ; \mathrm{a}_{5} \mathrm{Ru}-\right.$ (His-81) Mb: $\mathrm{Mb}=$ sperm whale myoglobin $)^{10}$ by zinc mesoporphyrin IX diacid ( $\mathrm{ZnP})$. The $\mathrm{ZnP}$ excited triplet state $\left({ }^{3} \mathrm{ZnP} *\right)$ is a much more powerful electron donor than a reduced heme $\left(\Delta E^{\circ}\left({ }^{3} \mathrm{ZnP}^{*}-\mathrm{Ru}^{3+} \rightarrow \mathrm{ZnP}^{+}-\mathrm{Ru}^{2+}\right) \sim 0.8 \mathrm{~V}\right),{ }^{11}$ thereby allowing four different electron-transfer distances to be examined in a single protein molecule.

\section{Experimental Section}

Materials and Apparatus. Distilled water, filtered through a Barnstead Nanopure water purification system (No. 2794, specific resistance $>18$ $\mathrm{M} \Omega \cdot \mathrm{cm}$ ), was used in the preparation of all aqueous solutions. 2-Butanone (MCB) was stored over aluminum oxide (Woelm neutral, Waters Associates) at $4^{\circ} \mathrm{C}$ to prevent the accumulation of peroxides. All other reagents were used as received.

Carboxymethylcellulose cation-exchange resin, CM-52 (Whatman, preswollen, microgranular), was equilibrated as indicated by the manufacturer (six-aliquot buffer changes). Five column volumes of buffer were passed to pack the column prior to use. CM-52 resins were cleaned after use by washing with a high-salt solution $(\sim 1-3 \mathrm{M} \mathrm{NaCl})$. Sephadex ion-exchange gel, G-25-80 (Sigma, bead size 20-80 $\mu \mathrm{m}$ ) was equilibrated in the desired buffer, slurried, and poured in a fashion similar to that described for CM-52. Sephadex gels were cleaned by multiple washings with buffer or water.

(16) (a) Williams, G.; Moore, G. R.; Williams, R. J. P. Comments Inorg. Chem. 1985, 4, 55-98. (b) Williams, R. J. P.: Concar, D. Nature (London) 1986, 322, 213-214. (c) Pielak, G. J.; Concar, D. W.; Moore, G. R.; Williams, R. J. P. Protein Eng. 1987, $1,83-88$.

(17) Marcus, R. A.; Sutin, N. Biochim. Biophys. Acta 1985, 811, 265-322.

(18) Hopfield, J. J. Proc. Natl. Acad. Sci. U.S.A. 1974, 71, 3640-3644.

(19) Hush, N. S. Coord. Chem. Rev. 1985, 64, 135-157.

(20) Larsson, S. J. Chem. Soc., Faraday Trans, 1983, 79, 1375-1388.

(21) Scott, R. A.; Mauk, A. G.; Gray, H. B. J. Chem. Educ. 1985, 62, 932-938. 
Samples were degassed and purged with purified argon (passed through a manganese oxide column) on a dual-manifold vacuum argon line. At least five vacuum/purge cycles were used to deoxygenate samples. Transfers were done anaerobically with a cannula (Aldrich, 20-gal stainless, noncoring tips). Other air-sensitive manipulations were performed under argon in a Vacuum Atmospheres Co. HE-43.2 Dri Lab inert-atmosphere box. Concentration of protein solutions and removal of small molecules were achieved with an Amicon ultrafiltration system (YM-5 filter, 5000 molecular weight cutoff).

Preparations and Purifications. The perchlorate ${ }^{22}$ and chloride ${ }^{23}$ salts of tris(1,10-phenanthroline)cobalt(III), Co(phen) ${ }_{3}{ }^{3+}$, were prepared by literature methods. A saturated solution of $\mathrm{Co}$ (phen) $3^{3+}$ was used to oxidize the protein samples.

Aquopentaammineruthenium(II) $\left(\mathrm{a}_{5} \mathrm{RuH}_{2} \mathrm{O}^{2+}\right)$ was synthesized by reduction of chloropentaammineruthenium(III) (Strem) by zinc amalgam. ${ }^{24}$ The product was precipitated as the hexafluorophosphate salt and stored under vacuum, or the $\mathrm{a}_{5} \mathrm{RuH}_{2} \mathrm{O}^{2+}$ solution was used directly in the labeling reaction with protein.

Purification of Sperm Whale Skeletal Muscle Ferrimyoglobin. Sigma ferrimyoglobin $(6 \mathrm{~g})$, metMb, was dissolved in $20 \mathrm{~mL}$ of Tris buffer ( $\mu$ $0.05 \mathrm{M}, \mathrm{pH} 7.2$ ). The protein solution was centrifuged to separate the insoluble material. The supernatant was applied to a CM-52 column (4 $\mathrm{cm} \times 80 \mathrm{~cm})$ equilibrated with Tris buffer $(\mu 0.05 \mathrm{M}, \mathrm{pH} 7.8)$ at $4^{\circ} \mathrm{C}$. The sample was eluted at $50 \mathrm{~mL} / \mathrm{h}$ with Tris buffer $(\mu 0.05 \mathrm{M}, \mathrm{pH} 7.2)$. Four separable bands were typically observed, and band IV (the richest in metMb) was used for these studies.

Preparation of Pentaammineruthenium(III) Ferrimyoglobin. ${ }^{10}$ A solution containing $60 \mathrm{mg}$ ( $25 \mathrm{~mL}$ of $1.3 \mathrm{mM}$ metMb) of ferrimyoglobin in Tris buffer $(\mu 0.05 \mathrm{M}, \mathrm{pH} 7.2)$ was degassed and purged with argon in a septum-stoppered $120-\mathrm{mL}$ bottle. Excessive foaming of the protein solution during degassing was avoided to minimize protein denaturation. A total of $130 \mathrm{mg}$ of degassed aquopentaammineruthenium(II) hexafluorophosphate was dissolved in $15 \mathrm{~mL}$ of argon-purged Tris buffer $(\mu$ $0.05 \mathrm{M}, \mathrm{pH} 7.2$ ).

The aquopentaammineruthenium(II) was transferred under argon to the ferrimyoglobin solution. The ferrimyoglobin immediately reduced, and the solution changed color from the brown to deep red. After the mixture had reacted without agitation at room temperature for $30 \mathrm{~min}$, the reaction was quenched by elution on a Sephadex G-25 column (Tris buffer, $\mu 0.05 \mathrm{M}, \mathrm{pH} 7.2)$. The protein fraction was collected, oxidized with $\mathrm{Co}$ (phen $)_{3}{ }^{3+}$, and stored at $4{ }^{\circ} \mathrm{C}$

Purification of Pentaammineruthenium(III) Ferrimyoglobin. ${ }^{10}$ The mixture of ruthenated myoglobins was desalted by five cycles of Amicon concentration and dilution with water and then reduced to a final volume of $6 \mathrm{~mL}$ ( $600 \mathrm{mg}, 5.6 \mathrm{mM}$ modified met $\mathrm{Mb}$ ). The modified myoglobins were separated by isoelectric focusing. An LKB system (2117 Multiphor, 2197 Electrofocusing Power Supply) was used. Two gels were prepared by standard procedures. ${ }^{25}$ To each gel was applied $3 \mathrm{~mL}$ of protein solution, and the gels were run at $4{ }^{\circ} \mathrm{C}$ (power supply settings: $1500 \mathrm{~V}$, $22 \mathrm{~mA}, 10 \mathrm{~W}$ ). Progress of the focusing was monitored visually by observing the separation of the modified myoglobin bands. When sufficient resolution of native, singly modified, and doubly modified bands occurred, the gels were stopped. The band of singly modified derivatives was cut from the trays and eluted from the gel through a disposable frit with water. The ampholytes were removed from the collected protein solution by Amicon ultrafiltration.

The mixture of singly ruthenated myoglobin derivatives was concentrated and loaded onto a CM-52 column (equilibrated with $\mu 0.1 \mathrm{M}$ Tris buffer, $\mathrm{pH} 7.8,4 \mathrm{~cm} \times 70 \mathrm{~cm}$ ) at $4^{\circ} \mathrm{C}$. The protein was eluted with Tris buffer at $50 \mathrm{~mL} / \mathrm{h}$. Four bands were collected, and each was concentrated and rechromatographed, if necessary. Fractions were kept at 4 ${ }^{\circ} \mathrm{C}$ for short-term storage or frozen at $-60^{\circ} \mathrm{C}(0.1 \mathrm{mM}$ protein $)$ in Tris buffer. $\mathrm{Co}(\text { phen })_{3}{ }^{3+}$ was added to all modified protein solutions for storage. The order of elution from the CM-52 column is a ${ }_{5} \mathrm{Ru}(\mathrm{His}$ 12) Mb, $a_{5} \mathrm{Ru}(\mathrm{His}-116) \mathrm{Mb}, \mathrm{a}_{5} \mathrm{Ru}(\mathrm{His}-81) \mathrm{Mb}$, and $\mathrm{a}_{5} \mathrm{Ru}(\mathrm{His}-48) \mathrm{Mb}$.

Preparation of Zinc Mesoporphyrin IX Diacid. The porphyrin dimethyl ester was first saponified to the diacid. A total of $250 \mathrm{mg}$ of mesoporphyrin IX dimethyl ester (Sigma) was dissolved in $5 \mathrm{~mL}$ of pyridine in a 50-mL three-neck flask. The flask was wrapped in foil and placed under an argon flow. A total of $20 \mathrm{~mL}$ of $1 \%$ potassium hydroxide in methanol $(0.29 \mathrm{~g}$ of $\mathrm{KOH}(89 \%)$ in $25 \mathrm{~mL}$ of $\mathrm{MeOH})$ was added with

(22) Schilt, A. A.; Taylor, R. C. Russ. J. Inorg. Chem. (Engl. Transl.) $1959,9,211-221$.

(23) Pfeiffer, P.: Werdeimann, B. Z. Anorg. Allg. Chem. 1950, 263, 31-38.

(24) Ford, P.: Rudd, De F. P.; Gaunder, R.; Taube, H. J. Am. Chem. Soc. 1968, $90,1187-1194$

(25) Winter, A.; Perlmutter, H.; Davies, H. Preparative Flat-Bed Electrofocusing in a Granulated Gel with the LKB 2117 Multiphor, Application Note 198 , revised 1980.
$3 \mathrm{~mL}$ of water. The reaction mixture was heated and refluxed for $2 \mathrm{~h}$ Hydrochloric acid $(6 \mathrm{~N})$ was added to precipitate the porphyrin diacid The reaction mixture was refrigerated overnight. The sample was centrifuged and decanted.

Zinc(II) was inserted into the free base by standard methods. ${ }^{26}$ Evaluation of the completeness of the reaction and purity of the product was done by thin-layer chromatography (EM Reagents, silca gel $60 \mathrm{~F}_{254}$ ). Samples were spotted from chloroform solution, and an 85:13.5:1.5 $(\mathrm{v} / \mathrm{v} / \mathrm{v})$ toluene/ethyl acetate/methanol solvent system was used as the developer. ${ }^{27}$ Progress of the chromatography was followed by sample luminescence under UV light. The zinc mesoporphyrin IX diacid was stored in a foil-wrapped vial at $-60^{\circ} \mathrm{C}$.

Preparation of Apomyoglobin. The heme was removed from the myoglobin by the acidic 2-butanone extraction method. ${ }^{28,29}$ On the final extraction, the aqueous apoprotein solution was removed and transferred to a Spectrapor dialysis bag (Spectrum Medical Industries; 20.4-mm diameter, $600-800$ molecular weight cutoff, $3.2 \mathrm{~mL} / \mathrm{cm}$ ) that had been previously cleaned by standard methods. The sample was twice dialyzed against $1 \mathrm{~L}$ of $10 \mathrm{mM}$ sodium bicarbonate $\left(3.36 \mathrm{~g}\right.$ of $\mathrm{NaHCO}_{3}$ in $4 \mathrm{~L}$ of $\mathrm{H}_{2} \mathrm{O}$ ) followed by three times against $1 \mathrm{~L}$ of $\mu 0.1 \mathrm{M}$ phosphate buffer $\mathrm{pH} 7.0$. Each dialysis was continued for $6-12 \mathrm{~h}$. The concentration of the apoprotein was determined from the absorption spectrum $\left(\epsilon_{280} 15.8\right.$ $\left.\mathrm{mM}^{-1} \mathrm{~cm}^{-1}\right){ }^{30}$ A minor peak at $424 \mathrm{~nm}$ indicated the incomplete removal of the iron porphyrin. Typically, heme removal in excess of $99 \%$ was achieved. Apoprotein prepared in this fashion was immediately used for reconstitution with the zinc mesoporphyrin.

Preparation of Reconstituted Myoglobin. ${ }^{31}$ The apoprotein solution was maintained at $4{ }^{\circ} \mathrm{C}$ or ice bath temperatures for the duration of the insertion process. Approximately $3 \mathrm{mg}$ of zinc mesoporphyrin IX diacid was dissolved in 10 drops of $0.1 \mathrm{~N} \mathrm{NaOH}(\mathrm{aq})$ in $5 \mathrm{~mL}$. A volume of 2 $\mathrm{mL}$ of phosphate buffer $(\mu 0.1 \mathrm{M}, \mathrm{pH} 7.0)$ was added to the porphyrin solution. The resulting solution was added dropwise to the apoprotein with gentle swirling. The mixture was stirred in the dark at $4^{\circ} \mathrm{C}$ for 12 $\mathrm{h}$. A second insertion was then made. After $12 \mathrm{~h}$ more, the solution was left undisturbed overnight. The sample was centrifuged for $1-2 \mathrm{~h}$, and the supernatant was decanted and saved for purification.

Purification of Reconstituted Myoglobins. The zinc mesoporphyrin IX reconstituted myoglobin was applied to a Sephadex G-25-80 column, equilibrated with phosphate buffer $(\mu 0.01 \mathrm{M}, \mathrm{pH} 7.0)$, and eluted with the same buffer at $4^{\circ} \mathrm{C}$. The protein band was collected and concentrated by Amicon ultrafiltration for loading on the phosphate $(\mu 0.01 \mathrm{M})$ equilibrated CM-52 column $(3 \mathrm{~cm} \times 22 \mathrm{~cm})$. An ionic strength gradient, $\mu 0.01-0.1 \mathrm{M}$, was used to elute the sample at $30 \mathrm{~mL} / \mathrm{h}$. Unmodified zinc myoglobin typically required $30-36 \mathrm{~h}$ to elute, and $72-84 \mathrm{~h}$ were required for the ruthenated derivatives. Additional $0.1 \mathrm{M}$ buffer was needed to complete some elutions. Zinc-substituted myoglobins were refrigerated in foil-wrapped vials and used as quickly as possible.

Analytical isoelectric focusing was used to determine the purity of the $a_{5} \mathrm{Ru}(\mathrm{His}) \mathrm{Mb}(\mathrm{ZnP})$ 's following final purification. ${ }^{32}$ The isoelectric point (pI) of $\mathrm{Mb}(\mathrm{ZnP})$ is the same as the $\mathrm{pI}$ of ferromyoglobin (pI 7.4). Apomyoglobin is readily resolved from the reconstituted protein, because its $\mathrm{pl}$ is between $\sim 8$ and 9 . The broad $\mathrm{pI}$ band indicates that the apomyoglobin consists of multiple components, probably a result of degradation of the less stable apoprotein. The $a_{5} R u(H i s) M b(Z n P)$ samples exhibit $\mathrm{p} \Gamma \mathrm{s}$ that correspond to reduced $\mathrm{a}_{5} \mathrm{Ru}(\mathrm{His}) \mathrm{Mb}$ derivatives. ${ }^{.1}$

Reconstitution of apomyoglobin with zinc mesoporphyrin IX diacid was greater than $90 \%$ based on protein recovery. The determination of $\mathrm{Mb}(\mathrm{ZnP})$ concentrations assumes that the $A_{280}$ extinction coefficients for apomyoglobin and $\mathrm{Mb}(\mathrm{ZnP})$ are similar. This assumption is supported by experimental results that correlate the amount of protein present before and after reconstitution with the UV-visible absorption data: ${ }^{33}$ $A_{414} / A_{280} \sim 16$, so $\epsilon_{414} \sim 250 \mathrm{mM}^{-1} \mathrm{~cm}^{-1}$.

(26) Adler, A. D.; Longa, F. R.; Kampas, F.; Kim, J. J. Inarg. Nucl. Chem 1970, 32, 2443-2445.

(27) Doss, M. Z. Klin. Chem. Klin. Biochem. 1970, 8, 208-211

(28) Teale, F. W. Biochim. Biophys. Acta 1959, 35, 543

(29) Yonetani, T. J. Biol. Chem. 1967, 242, 5008-5013.

(30) Stryer, L. J. J. Mol. Biol. 1965, 13, 482-495.

(31) Leonard, J. J.; Yonetani, T.; Callis, J. B. Biochemistry 1974, 13, 1460-1464.

(32) LKB Ampholine polyacrylamide gel plates (PAG plates) were used $\mathrm{pH}$ range 3.5-9.5 (LKB 1804-101).

(33) After heme extraction (17.2 $\mathrm{mg}, A_{280} 0.355, \in 15.8 \mathrm{mM}^{-1} \mathrm{~cm}^{-1}, 17200$ Da) (Edmundson, A. B.: Hirs, C. H. W. J. Mol. Biol. 1962, 5, 663-682), 45 $\mathrm{mL}$ of protein was available for reconstitution. The zinc mesoporphyrin was inserted, and following centrifugation and a Sephadex G-25 column, $17.5 \mathrm{mg}$ $(A 0.403,40 \mathrm{~mL})$ was recovered. The amount of reconstituted protein is in apomyoglobin equivalents (the zinc porphyrin is not included in the calculation). 
Table I. Electron-Transfer Rate Constants for $\mathrm{a}_{5} \mathrm{Ru}(\mathrm{His}) \mathrm{Mb}(\mathrm{ZnP})$ Derivatives

\begin{tabular}{|c|c|c|c|c|c|c|c|c|}
\hline \multirow[b]{2}{*}{ temp, ${ }^{\circ} \mathrm{C}( \pm 0.1)$} & \multirow{2}{*}{$\begin{array}{c}\mathrm{Mb}(\mathrm{ZnP}) \\
k_{\text {obsd }},{ }^{a} \mathrm{~s}^{-1}\end{array}$} & \multirow{2}{*}{$\begin{array}{l}\text { His-48: } \\
k_{f}^{b}, \mathrm{~s}^{-1}\end{array}$} & \multicolumn{2}{|c|}{ His- 81} & \multicolumn{2}{|c|}{ His-116 } & \multicolumn{2}{|c|}{ His -12} \\
\hline & & & $k_{\text {obad, }}{ }^{a} \mathrm{~s}^{-1}$ & $k_{\mathrm{f}}, \mathrm{s}^{-1}$ & $k_{\text {obsd }},{ }^{0} \mathrm{~s}^{-1}$ & $k_{f}{ }^{c} \mathrm{~s}^{-1}$ & $k_{\text {obsd }},{ }^{a} s^{-1}$ & $k_{f},{ }^{c} s^{-1}$ \\
\hline 7.6 & $3.8 \pm 0.5$ & $5.4 \pm 0.9$ & $7.4 \pm 0.2$ & $3.6 \pm 0.5$ & $8.6 \pm 0.6$ & $4.8 \pm 0.8$ & $9.9 \pm 0.7$ & $6.1 \pm 0.9$ \\
\hline 11.8 & $3.9 \pm 0.4$ & $6.2 \pm 0.8$ & $9.0 \pm 1.3$ & $5.1 \pm 1.4$ & $9.2 \pm 0.4$ & $5.4 \pm 0.6$ & $10.3 \neq 0.3$ & $6.4 \pm 0.5$ \\
\hline 16.2 & $3.9 \pm 0.3$ & $6.2 \pm 0.6$ & $9.7 \pm 0.8$ & $5.8 \pm 0.9$ & $10.5 \pm 0.2$ & $6.6 \pm 0.4$ & $11.7 \pm 0.3$ & $7.8 \pm 0.4$ \\
\hline 20.6 & $4.0 \pm 0.3$ & $6.3 \pm 1.3$ & $11.2 \pm 1.0$ & $7.3 \pm 1.0$ & $11.4 \pm 1.2$ & $7.5 \pm 1.2$ & $11.9 \pm 1.6$ & $8.0 \pm 1.6$ \\
\hline 25.0 & $4.0 \pm 0.2$ & $7.0 \pm 0.8$ & $12.6 \pm 1.2$ & $8.6 \pm 1.2$ & $13.0 \pm 0.2$ & $8.9 \pm 0.3$ & $14.1 \pm 1.1$ & $10.1 \pm 1.1$ \\
\hline 29.4 & $4.1 \pm 0.2$ & $7.7 \pm 1.4$ & $13.8 \pm 0.5$ & $9.7 \pm 0.5$ & $14.4 \pm 0.7$ & $10.3 \pm 0.7$ & $15.7 \pm 1.9$ & $11,6 \pm 1.9$ \\
\hline 34.0 & $4.2 \pm 0.2$ & $8.0 \pm 1.0$ & $15.2 \pm 2.2$ & $11.0 \pm 2.2$ & $15.9 \pm 0.1$ & $11.7 \pm 0.2$ & $17.4 \pm 0.5$ & $13.3 \pm 0.5$ \\
\hline 38.6 & $4.2 \pm 0.1$ & $8.1 \pm 1.4$ & $17.2 \pm 2.1$ & $13.0 \pm 2.1$ & $18.3 \pm 2.2$ & $14.1 \pm 2.2$ & $19.2 \pm 1.7$ & $15.0 \pm 1.7$ \\
\hline
\end{tabular}

${ }^{a} k_{\text {obsd }} \times 10^{-1} \cdot{ }^{b} k_{\mathrm{f}} \times 10^{-4} \cdot{ }^{c} k_{\mathrm{f}} \times 10^{-1}$.

Instrumentation. Transient absorption lifetime measurements were made with a pulsed-laser system described previously. ${ }^{\text {if }}$ Modifications to the system for transient absorption measurements are indicated below. Samples ( $\mu 0.1 \mathrm{M}$, phosphate buffer $\mathrm{pH} 7.0, A_{414} \sim 1.25$ ) were degassed in a vacuum cell with a $1-\mathrm{cm}$ fluorescence cuvette side arm. A $500-W$ continuous-wave tungsten lamp with an Infrared Industries Model 518 lamp power supply served as the probe beam source. The beam was collimated $(f 17.7 \mathrm{~cm}$, diameter $7.5 \mathrm{~cm})$ in the lamp housing and focused by a lens $(f 15.2 \mathrm{~cm}$, diameter $10.0 \mathrm{~cm})$ through a series of Corning filters, $0-52,0-51,5-57$, and $5-58$. The beam was cropped by a $0.8-\mathrm{cm}$ aperature and passed through the sample cell. The beam was refocused $(f 7.0 \mathrm{~cm}$, diameter $3.8 \mathrm{~cm})$ onto the slit of the monochromator $(0.8 \mathrm{~mm})$ through a Corning 5057 filter. A Tektronix FET probe amplifier with a $5-\mathrm{k} \Omega$ resistor was used for all transients except the $a_{5} \mathrm{Ru}(\mathrm{His}-48) \mathrm{Mb}$ $(\mathrm{ZnP})$ system, in which case a LeCroy amplifier was used. A total of 40 pulses was taken at $1 \mathrm{~Hz}$, and the data were averaged on a PDP computer. Data were serially transferred to an IBM PCAT for later analysis and graphics. Data were analyzed with nonlinear least-squares routines. Both monophasic and biphasic first-order fits with zero and nonzero endpoints were made

\section{Results and Discussion}

Electron-transfer rates were determined from the quenching of the ${ }^{3} \mathrm{ZnP} \mathrm{P}^{*}$ decay. The long-lived triplet excited state reduces histidine-bound ruthenium(III) $\left(\Delta E^{\circ} \sim 0.8 \mathrm{~V}\right)$, and back electron transfer to $\mathrm{ZnP}^{+}$rapidly returns the system to its initial state $\left(k_{\mathrm{b}}\right.$ $>k_{\mathrm{f}}$ ) (eq 1$)^{11,34,35}$

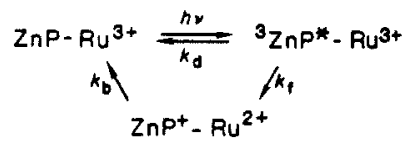

The native $\mathrm{Mb}(\mathrm{ZnP})$ data fit a monophasic first-order nonzero end point expression for at least 4 half-lives. The rate constant $\left(k_{\mathrm{d}}\right)$ obtained from this fit is $40 \pm 2 \mathrm{~s}^{-1}$ at $25^{\circ} \mathrm{C}$. The $\mathrm{Mb}\left({ }^{3} \mathrm{ZnP} \mathrm{P}^{*}\right)$ decay rate does not vary significantly from $7.6^{\circ} \mathrm{C}\left(38 \pm 5 \mathrm{~s}^{-1}\right)$ to $38.6^{\circ} \mathrm{C}\left(42 \pm 1 \mathrm{~s}^{-1}\right)$ (Table I). Values of $k_{\mathrm{d}}$ determined at 3 and $90 \mu \mathrm{M}$ are $41 \pm 2$ and $46 \pm 4 \mathrm{~s}^{-1}$, respectively, confirming that no bimolecular quenching of $\mathrm{Mb}\left({ }^{3} \mathrm{ZnP} *\right)$ occurs.

The $\mathrm{a}_{5} \mathrm{Ru}(\mathrm{His}-48) \mathrm{Mb}(\mathrm{ZnP})$ data also fit a monophasic firstorder nonzero end point expression for at least 4 half-lives (Figure 1). A rate constant of $(7.0 \pm 0.8) \times 10^{4} \mathrm{~s}^{-1}$ was obtained. Subtraction of the intrinsic decay rate $\left(40 \pm 2 \mathrm{~s}^{-1}\right)$ does not affect this result $\left(k_{\text {obsd }} \sim k_{f}\right)$. The decay of photoexcited $a_{5} R u($ His48) $\mathrm{Mb}(\mathrm{ZnP})$ also was measured following dithionite reduction ${ }^{36}$ of $a_{5} \mathrm{Ru}(\mathrm{His}-48)^{3+}$; the observed decay rate $\left(50 \pm 5 \mathrm{~s}^{-1}\right)$ is nearly the same as $k_{\mathrm{d}}$. The $\mathrm{a}_{5} \mathrm{Ru}(\mathrm{His}-48) \mathrm{Mb}\left({ }^{3} \mathrm{ZnP} *\right)$ quenching rate constant exhibits a slight temperature dependence (Table I), ranging from $(5.4 \pm 0.9) \times 10^{4} \mathrm{~s}^{-1}\left(7.6^{\circ} \mathrm{C}\right)$ to $(8.1 \pm 1.4) \times 10^{4}$ $\mathrm{s}^{-1}\left(38.6^{\circ} \mathrm{C}\right)$.

Residuals corresponding to a monophasic first-order nonzero end point fit of the $a_{5} \mathrm{Ru}(\mathrm{His}-81) \mathrm{Mb}(\mathrm{ZnP})$ data indicate a de-

(34) Elias, H.; Chou, M. H.; Winkler, J. R. J. Am. Chem. Soc., in press. (35) Under pulsed-laser experimental conditions, the $a_{5} \mathrm{Ru}(\mathrm{His}) \mathrm{Mb}(\mathrm{ZnP})$ samples are quite stable. The absorption spectra remain unchanged after 500 laser pulses. A slow reversible decay amounting to about $10 \%$ of the transient optical density change is attributable to protein impurities. ${ }^{30}$ The initial optical density is restored within $1 \mathrm{~s}$ of the excitation pulse (8-ns fwhm, $1-\mathrm{Hz}$ repetition). In contrast, when using a broad-band microsecond excitation source, the sample undergoes significant decomposition $(\sim 50 \%)$ within five flashes.

(36) Samples were treated with sodium dithionite in an inert-atmosphere box. Excess dithionite was removed by four cycles of concentration and dilution with an Amicon ultrafiltration unit.
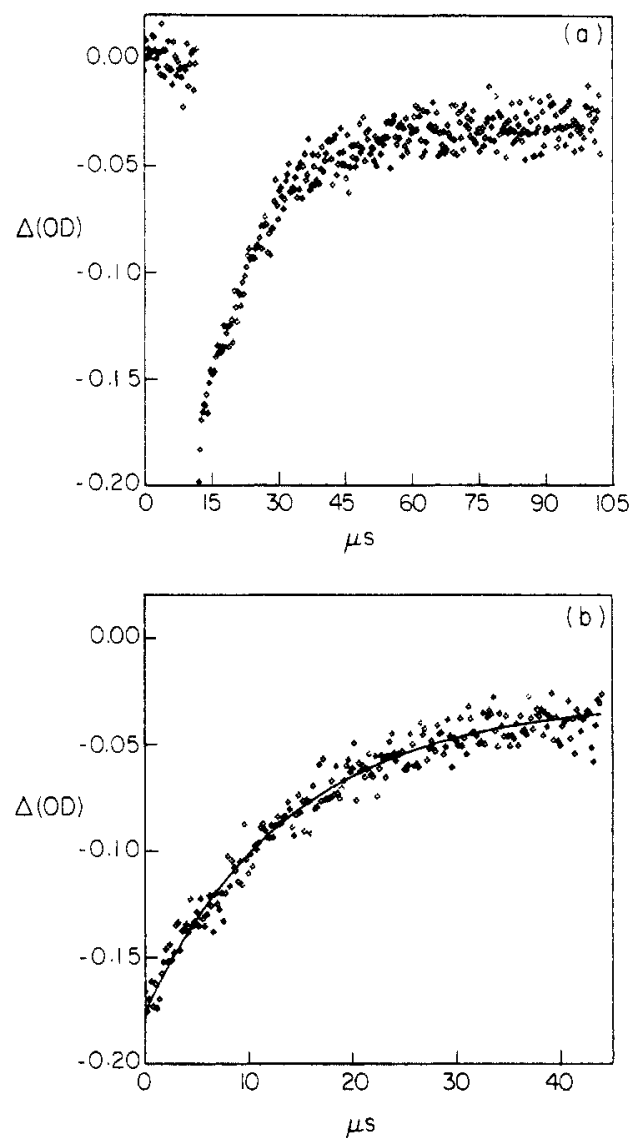

Figure 1. (a) Time-resolved 414-nm transient absorption of $a_{5} \mathrm{Ru}$ (His48) $\mathrm{Mb}(\mathrm{ZnP})$ at $25^{\circ} \mathrm{C}$ following $532-\mathrm{nm}$ laser excitation; (b) analysis of $a_{5} \mathrm{Ru}(\mathrm{His}-48) \mathrm{Mb}(\mathrm{ZnP})$ data (monophasic first-order nonzero end point).

viation from monophasic behavior. These data can be satisfactorily fit to a biphasic first-order zero endpoint expression. A total of 9 half-lives of the fast component was used in the analysis. The observed rate $\left(126 \pm 12 \mathrm{~s}^{-1}\right)$ corresponds to a $k_{\mathrm{f}}$ of $86 \pm 12 \mathrm{~s}^{-1}$. The second component contributes less than $10 \%$ to the transient absorption measurement and was observed for less than 2 halflives. Over the range 3-15 $\mu \mathrm{M}, \mathrm{a}_{5} \mathrm{Ru}(\mathrm{His}-81) \mathrm{Mb}(\mathrm{ZnP})$ showed no variation in $k_{\text {obsd }}$; following reduction ${ }^{36}$ of $\mathrm{a}_{5} \mathrm{Ru}(\mathrm{His}-81)^{3+}$, the observed rate $\left(45 \pm 4 \mathrm{~s}^{-1}\right)$ was found to be within experimental error of $k_{\mathrm{d}}$.

Similar analyses of the $a_{5} \mathrm{Ru}(\mathrm{His}-116) \mathrm{Mb}(\mathrm{ZnP})$ and $\mathrm{a}_{5} \mathrm{Ru}-$ (His-12) Mb $(\mathrm{ZnP})$ data yielded electron-transfer rate constants of $89 \pm 3$ and $101 \pm 11 \mathrm{~s}^{-1}$, respectively. The His-81, -116 , and -12 derivatives exhibit moderate temperature dependences (Table I). Enthalpies of activation $\left(\Delta H^{*}, \mathrm{kcal} \mathrm{mol}^{-1}\right)$ are as follows: $\mathrm{Mb}(\mathrm{ZnP}), 0.0 \pm 0.9 ; \mathrm{a}_{5} \mathrm{Ru}($ His-48) $\mathrm{Mb}(\mathrm{ZnP}), 1.7 \pm 1.6 ;$ His-81, $5.6 \pm 2.5$; His-116, 5.4 \pm 0.4 ; His-12, $4.7 \pm 0.9 .{ }^{37}$

(37) The results of more extensive studies of the effects of temperature on electron-transfer rates in $a_{5} R u M b(Z n P)$ and $a_{5} R u M b(M g P)$ derivatives are discussed elsewhere. Cowan, J. A.; Upmacis, R. K.; Gray, H. B. Recl. Trav. Chim. Pays-Bas 1987, 106, 289. Cowan, J. A.; Gray, H. B. Chem. Scr., in press. Upmacis, R. K.; Gray, H. B., to be submitted for publication. 


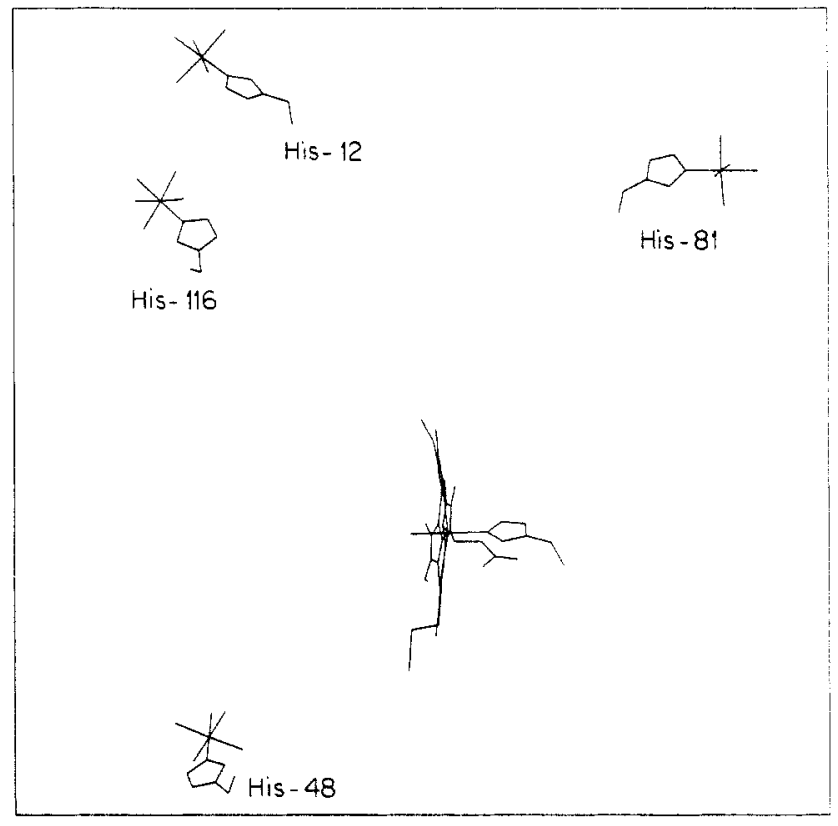

Figure 2. View of the heme and the surface histidines that are modified in the four ruthenated myoglobins.

Table II. Electron-Transfer Distances for Ruthenated Heme Proteins $^{a}$

\begin{tabular}{lcc}
\hline \multicolumn{1}{c}{ derivative } & $d$ range, $\AA$ & $d_{\mathrm{m}}$ range, $\AA$ \\
\hline $\mathrm{a}_{5} \mathrm{Ru}($ His-33)cyt $c$ & $10.8-11.7[11.6]$ & $16.1-18.8[18.3]$ \\
$\mathrm{a}_{5} \mathrm{Ru}(\mathrm{His}-48) \mathrm{Mb}$ & $11.8-16.6[12.7]$ & $16.6-23.9[17.1]$ \\
$\mathrm{a}_{5} \mathrm{Ru}(\mathrm{His}-81) \mathrm{Mb}$ & $18.8-19.3[19.3]$ & $24.1-26.6[25.1]$ \\
$\mathrm{a}_{5} \mathrm{Ru}(\mathrm{His}-116) \mathrm{Mb}$ & $19.8-20.4[20.1]$ & $26.8-27.8[27.7]$ \\
$\mathrm{a}_{5} \mathrm{Ru}($ His-12)Mb & $21.5-22.3[22.0]$ & $27.8-30.5[29.3]$ \\
\hline
\end{tabular}

${ }^{\circ}$ The distances are lower and upper values at $6.5 \mathrm{kcal}$ above the potential energy minimum. The value at the minimum is in brackets.

Distance Dependence. Theory indicates that the rate of longrange electron transfer will fall off exponentially with donoracceptor distance. ${ }^{17}$ Both edge-edge $(d)$ and metal-metal $\left(d_{\mathrm{m}}\right)$ distances were examined in our analysis. ${ }^{38}$ Assuming an electronic transmission coefficient of unity when ${ }^{3} \mathrm{ZnP}^{*}$ and $\mathrm{a}_{5} \mathrm{Ru}(\mathrm{His})^{3+}$ are in van der Waals edge-edge contact $(d=3 \AA),{ }^{39}$ the standard theoretical expression for the electron-transfer rate constant is eq 2 , where $\lambda$ is the vertical reorganization energy and $\Delta G^{\circ}$ is the reaction free energy. ${ }^{17}$

$k_{\mathrm{f}}=10^{13} \exp \left[-\left(\lambda+\Delta G^{\circ}\right)^{2} / 4 \lambda R T\right] \exp [-\beta(d-3)] \mathrm{s}^{-1}$

Electron-transfer distances for the various $\mathrm{Mb}$ derivatives (Figure 2) and for $\mathrm{a}_{5} \mathrm{Ru}(\mathrm{His}-33$ )-cytochrome $c$ were obtained from a rigid-body conformational search ${ }^{40}$ of the appropriately modified sperm whale myoglobin and tuna cytochrome $c$ structures. ${ }^{41}$ The searches were performed by evaluating the van der Waals energy of the $10^{4}$ unique conformations that are generated by successively incrementing each of the two histidine (modified with $a_{5} R u$ )

(38) The distance between $\mathrm{Ru}$ and $\mathrm{Zn}$ is $d_{\mathrm{m}}$; the closest distance between the $\mathrm{Ru}$ ligand atoms (the five ring atoms of histidine and the five nitrogen atoms of the ammines) and the $\mathrm{Zn}$ ligand atoms (the five ring atoms of the histidine and the porphyrin-ring atoms) is $d$.

(39) Electron transfer should be facile at the van der Waals edge-edge contact because there are relatively low lying imidazole to $\mathrm{Ru}^{3+}$ chargetransfer states that should interact strongly with the delocalized $\pi$-donor level of ${ }^{3} \mathrm{ZnP}$ : Krogh-Jespersen, K.; Schugar, H. J. Inorg. Chem. 1984, 23 , 4390-4393. Krogh-Jespersen, K.; Westbrook, J. D.; Potenza, J. A.; Schugar, H. J. J. Am. Chem. Soc. 1987, 109, 7025-7031.

(40) (a) Gelin, B. R.; Karplus, M. Biochemistry 1979, 18, 1256-1268. (b) Calculations were performed with BIOGRAF/III version 1.23: BIOGRAF was designed and written by S. L. Mayo, B. D. Olafson, and W. A. Goddard III

(41) (a) Protein coordinates were obtained from the Brookhaven Protein Data Bank: Bernstein, F. C.; Koetzle, T. F.; Williams, G. J. B.; Meyer, Jr. E. F.; Brice, M. D.; Rodgers, J. R.; Kennard, O.; Shimanouchi, T.; Tasumi, M. J. Mol. Biol. 1977, 112, 535-542. (b) Tuna cytochrome $c$ (Trp-33 replaced by $a_{5} \mathrm{Ru}(\mathrm{His})$ ) served as the structural model for the horse heart protein.

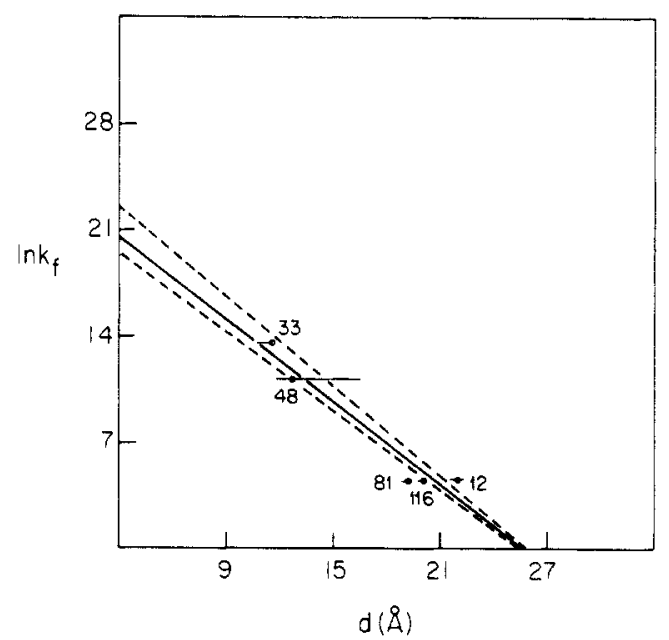

Figure 3. Distance dependence of $\ln k_{f}: 33$, $a_{5} R u(H i s-33) c y t c(Z n P)$; other numbers, the $a_{5} \mathrm{Ru}(\mathrm{His}) \mathrm{Mb}(\mathrm{ZnP})$ derivatives. The lines are least-squares fits to $6.5 \mathrm{kcal}$ lower limit/upper limit (-.) and minimum energy ( - ) $d$ values.

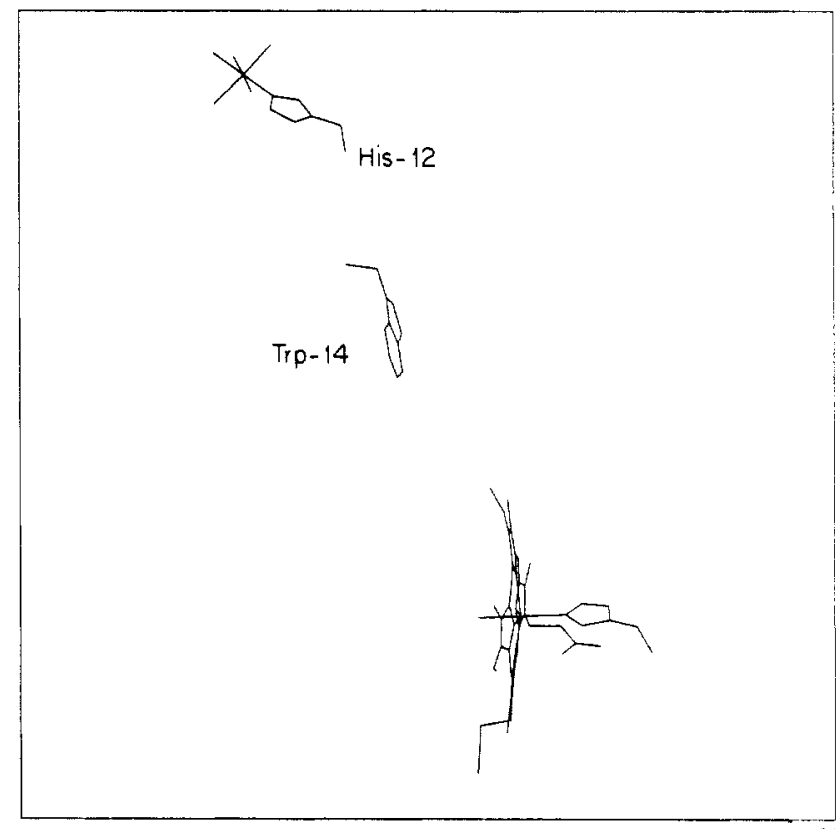

Figure 4. View of the Trp-14 between the porphyrin and Ru(His-12) ${ }^{3+}$ in $\mathrm{a}_{5} \mathrm{Ru}(\mathrm{His}-12) \mathrm{Mb}$.

side-chain dihedral angles by $3.6^{\circ}$. The calculation included only the van der Waals contribution of those atoms within $8.5 \AA$ of the ruthenated histidine in each conformation. Pseudo potential energy surfaces were obtained by plotting conformational energy vs electron-transfer distance ( $d$ or $d_{\mathrm{m}}$ ) and by fitting a smooth curve under the generated points. A comparison of the experimental structure ${ }^{42}$ of $\mathrm{a}_{5} \mathrm{Ru}(\mathrm{His}-48) \mathrm{Mb}$ reveals an uncertainty of at least $6.5 \mathrm{kcal}$ in our calculations. That is, the experimental $d_{\mathrm{m}}$ of $24 \AA$ falls on our potential energy surface approximately $6.5 \mathrm{kcal}$ above the calculated minimum. The $d$ and $d_{\mathrm{m}}$ ranges in our analysis of the rates reflect this 6.5 -kcal uncertainty (Table II).

The ln $k_{\mathrm{f}}$ vs $d$ plot for the $\mathrm{a}_{5} \mathrm{RuMb}$ and $\mathrm{a}_{5} \mathrm{Ru}-\mathrm{cyt} c^{34}$ experiments is shown in Figure 3. The experimental distance dependence of the rate constant is given by eq 3 . Best fits to the lower

$$
k_{\mathrm{f}}=7.8 \times 10^{8} \exp [-0.91(d-3)] \mathrm{s}^{-1}
$$

and upper limits of the $d$ ranges give $k_{f}=2.8 \times 10^{8} \exp [-0.87(d$ $-3)] \mathrm{s}^{-1}$ and $k_{\mathrm{f}}=5.8 \times 10^{9} \exp [-0.99(d-3)] \mathrm{s}^{-1}$, respectively, thereby providing a measure of the uncertainty in eq $3 .{ }^{43}$

(42) Mottonen, J.; Ringe, D.; Petsko, G. A., unpublished results. 
Our finding that $\beta$ for long-range protein electron transfers $\left(0.9-1.0 \AA^{-1}\right)$ is somewhat smaller than commonly assumed values (1.2-1.4 $\AA^{-1}$ ) is supported by the observation that the three longest transfers all occur at roughly the same rate, even though $d$ is $2-3$ $\AA$ larger for the His-12 derivative than for the other two species. Examination of $\mathrm{a}_{5} \mathrm{Ru}(\mathrm{His}-12) \mathrm{Mb}$ with computer graphics shows that an aromatic group (Trp-14) is parallel-planar to $\mathrm{ZnP}$ in the medium between the porphyrin and His-12 (Figure 4), thereby raising the possibility that weak ${ }^{3} \mathrm{ZnP} *(\operatorname{Trp}-14) \mathrm{a}_{5} \mathrm{Ru}(\mathrm{His}-12)^{3+}$ charge-transfer interactions might facilitate electron transfer. ${ }^{44}$ However, an extensive theoretical analysis of the $\mathrm{ZnP}$ to $\mathrm{a}_{5} \mathrm{Ru}-$ (His-12) pathway by Kuki and Wolynes ${ }^{45}$ does not support a

(43) For comparison, the $\beta$ 's are 0.75 and $0.90 \AA^{-1}$ for the lower and upper $d_{\mathrm{m}}$ limits. The driving-force dependences of the electron-transfer rates indicate that $\lambda$ is $1.90-2.45 \mathrm{eV}$ for Ru(His-48)Mb if $\beta$ is $0.91 \AA^{-1}$ : Karas, J. L.; Lieber, C. M.; Gray, H. B. Abstracts of Papers, 193rd National Meeting of the American Chemical Society, Denver, CO; American Chemical Society: Washington, DC, April 1987; INOR 149, submitted for publication in J. Am. Chem. Soc.

(44) Calculations assuming a nearly optimal orientation indicate that Trp-14 could enhance the donor-acceptor electronic coupling: Onuchic, J N.; Beratan, D. N. J. Am. Chem. Soc. 1987, 109, 6771-6778.

(45) Kuki, A.; Wolynes, P. G. Science (Washington, D.C.) 1987, 236, 1647-1652. special role for the intervening tryptophan, and the relatively small departure of the His-12 derivative from the rate-distance correlation (eq 3) may have an entirely different origin. Hoffman, Mauk, and co-workers have found only minor effects on cytochrome $c$ peroxidase $\left({ }^{3} \mathrm{ZnP}\right) \|$ cytochrome $c\left(\mathrm{Fe}^{3+}\right)$ long-range electron-transfer rates upon changing Phe- 82 of cyt $c$ to other residues, although dramatic differences in the reverse-direction transfers $\left(\mathrm{Fe}^{2+}\right.$ to $\left.\mathrm{ZnP}^{+}\right)$were observed. ${ }^{14}$ Further work on the influence of the medium in well-defined electron-transfer systems is called for, because it is apparent from these early experimental and theoretical results that many issues need to be explored in greater depth.

Acknowledgment. We thank Charlie Lieber, Jenny Karas, Walther Ellis, Lorne Reid, Jose Onuchic, David Beratan, A. Kuki, Harvey Schugar, R. A. Marcus, and Jay Winkler for helpful discussions. A.W.A. acknowledges a fellowship from the Fannie and John Hertz Foundation. S.L.M. acknowledges a fellowship from AT\&T Bell Laboratories. This research was supported by National Science Foundation Grants CHE85-18793 and CHE85-09637.

Registry No. ZnP, 14354-67-7; His, 71-00-1; Trp, 73-22-3; mesoporphyrin IX dimethyl ester, 1263-63-4.

\title{
Reactivity of Trimetallic Organoyttrium Hydride Complexes. Synthesis of the Alkoxy Hydride Anions $\left[\left[\left(\mathrm{C}_{5} \mathrm{H}_{5}\right)_{2} \mathrm{Y}(\mu-\mathrm{H})\right]_{x}\left[\left(\mathrm{C}_{5} \mathrm{H}_{5}\right)_{2} \mathrm{Y}\left(\mu-\mathrm{OCH}_{3}\right)\right]_{3-x}\left(\mu_{3}-\mathrm{H}\right)\right]^{-}(x=0-2)$ Including the $\mathrm{X}$-ray Crystal Structure of $\left[\left[\left(\mathrm{C}_{5} \mathrm{H}_{5}\right)_{2} \mathrm{Y}\left(\mu-\mathrm{OCH}_{3}\right)\right]_{3}\left(\mu_{3}-\mathrm{H}\right)\right]_{2}\left[\mathrm{Li}(\mathrm{THF})_{3}\right]_{2}{ }^{1,2}$
}

\author{
William J. Evans, ${ }^{* 3 a}$ Mark S. Sollberger, ${ }^{3 a}$ Saeed I. Khan, ${ }^{3 b}$ and Robert Bau ${ }^{* 3 b}$ \\ Contribution from the Departments of Chemistry, University of California, Irvine, Irvine, \\ California 92717, and University of Southern California, Los Angeles, California 90089. \\ Received February 17, 1987
}

\begin{abstract}
C}_{5} \mathrm{H}_{5}\right)_{2} \mathrm{Y}(\mu-\mathrm{H})\right]_{3}\left(\mu_{3}-\mathrm{H}\right)\right]\left[\mathrm{Li}(\mathrm{THF})_{4}\right]$ (1) reacts with 1 equiv of $\mathrm{CH}_{3} \mathrm{OH}$ at $0{ }^{\circ} \mathrm{C}$ to form $\left[\left[\left(\mathrm{C}_{5} \mathrm{H}_{5}\right)_{2} \mathrm{Y}(\mu-\right.\right.$ $\left.\left.\left.\mathrm{OCH}_{3}\right)\right]\left[\left(\mathrm{C}_{5} \mathrm{H}_{5}\right){ }_{2} \mathrm{Y}(\mu-\mathrm{H})\right]_{2}\left(\mu_{3}-\mathrm{H}\right)\right]\left[\mathrm{Li}(\mathrm{THF})_{4}\right](2)$. Reaction of 1 with 2 equiv of $\mathrm{CH}_{3} \mathrm{OH}$ or 2 with 1 equiv of $\mathrm{CH}_{3} \mathrm{OH}$ at $0{ }^{\circ} \mathrm{C}$ forms $\left[\left[\left(\mathrm{C}_{5} \mathrm{H}_{5}\right)_{2} \mathrm{Y}\left(\mu-\mathrm{OCH}_{3}\right)\right]_{2}\left[\left(\mathrm{C}_{5} \mathrm{H}_{5}\right)_{2} \mathrm{Y}(\mu-\mathrm{H})\right]\left(\mu_{3}-\mathrm{H}\right)\right]\left[\mathrm{Li}(\mathrm{THF})_{4}\right](3)$. $\left[\left[\left(\mathrm{C}_{5} \mathrm{H}_{5}\right)_{2} \mathrm{Y}\left(\mu-\mathrm{OCH}_{3}\right)\right]_{3}\left(\mu_{3}-\mathrm{H}\right)\right]\left[\mathrm{Li}(\mathrm{THF})_{4}\right](4)$ can be formed from 1-3 with the appropriate amount of $\mathrm{CH}_{3} \mathrm{OH}$ at $0{ }^{\circ} \mathrm{C}$. The central $\mu_{3}-\mathrm{H}$ of these trimers does not react with $\mathrm{CH}_{3} \mathrm{OH}$. All trimetallic species were identified by elemental analysis, hydrolytic decomposition and ${ }^{1} \mathrm{H}$ NMR spectroscopy. Crystallization of 4 from THF gives $\left[\left[\left(\mathrm{C}_{5} \mathrm{H}_{5}\right)_{2} \mathrm{Y}\left(\mu-\mathrm{OCH}_{3}\right)\right]_{3}\left(\mu_{3}-\mathrm{H}\right)\right]_{2}\left[\mathrm{Li}(\mathrm{THF})_{3}\right]_{2}(5)$ in space group $P 2_{1} / n$ with the following unit cell dimensions: $a=20.852(9), b=13.984(5), c=31.590(9) \AA ; \beta=92.48(4)^{\circ} ; V=9203(7) \AA^{3}, Z=8 ; D_{\text {calcd }}=$ $1.81 \mathrm{~g} \mathrm{~cm}^{-3}$. Least-squares refinement on the basis of 2987 observed reflections led to a final $R$ value of 0.080 . The structure contains an anionic $\left[\left(\mathrm{C}_{5} \mathrm{H}_{5}\right)_{2} \mathrm{Y}\left(\mu-\mathrm{OCH}_{3}\right)\right]_{3}\left(\mu_{3}-\mathrm{H}\right)^{-}$unit, which has a triangular arrangement of three $\left(\mathrm{C}_{5} \mathrm{H}_{5}\right)_{2} \mathrm{Y}$ units bridged by methoxide groups. The central hydride ligand was not located but was observable by ${ }^{\mathrm{I}} \mathrm{H}$ NMR spectroscopy. The cation in 5 is comprised of a trimetallic anion like that just described, to which are attached two (THF) ${ }_{3} \mathrm{Li}$ groups, i.e., $\left[\left[(\mathrm{THF})_{3} \mathrm{Li}\left(\mu-\eta^{1}, \eta^{5}-\mathrm{C}_{5} \mathrm{H}_{5}\right)\left(\mathrm{C}_{5} \mathrm{H}_{5}\right) \mathrm{Y}\left(\mu-\mathrm{OCH}_{3}\right)\right]_{2}\left[\left(\mathrm{C}_{5} \mathrm{H}_{5}\right)_{2} \mathrm{Y}\left(\mu-\mathrm{OCH}_{3}\right)\right]\left(\mu_{3}-\mathrm{H}\right)\right]^{+}$. The (THF) ${ }_{3} \mathrm{Li}$ units bind on the same side of the trimetallic plane to carbon atoms in two different $\mathrm{C}_{5} \mathrm{H}_{5}$ rings with $\mathrm{Li}-\mathrm{C}$ distances of $2.50(8)-2.67$ (5) $\AA$. The two trimetallic parts are otherwise similar, with average $\mathrm{Y}-\mathrm{O}\left(\mathrm{OCH}_{3}\right)$ and $\mathrm{Y}-\mathrm{C}\left(\mathrm{C}_{5} \mathrm{H}_{5}\right)$ distances of 2.28 (2) and 2.73 (2) $\AA$.
\end{abstract}

In the course of studying the first crystallographically characterized molecular lanthanide hydrides, ${ }^{4}$ we discovered an unusual class of trimetallic hydrides, $\left[\left[\left(\mathrm{C}_{5} \mathrm{H}_{5}\right)_{2} \mathrm{Ln}(\mu-\mathrm{H})\right]_{3}\left(\mu_{3}-\mathrm{H}\right)\right][\mathrm{Li}-$

(1) Reported in part at the 191 st National Meeting of the American Chemical Society, New York, NY, April 1986, and at the 2nd International Conference on the Chemistry and Technology of the Lanthanides and Actinides, Lisbon, Portugal, April 1987; p (1)19. Organolanthanide and Organoyttrium Hydride Chemistry. $10{ }^{2}$

(2) Part 9: Evans, W. J.; Drummond, D. K.; Hanusa, T. P.; Doedens, R. J. Organometallics 1987, 6, 2279-2285 ifornia.
$\left.(\mathrm{THF})_{4}\right]\left(\mathrm{Ln}=\mathrm{Lu},{ }^{5} \mathrm{Y}^{6} \mathrm{Er}^{7}\right)$, in which three $\left(\mathrm{C}_{5} \mathrm{H}_{5}\right)_{2} \mathrm{Ln}(\mu-\mathrm{H})$ units surround a central hydride ion:

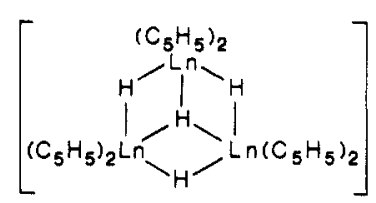

(4) Evans, W. J.; Meadows, J. H.; Wayda, A. L.; Hunter, W. E.; Atwood, J. L. J. Am. Chem. Soc. 1982, 104, 2008-2014. 